\title{
Mısır silajının besin ve besleme değerini etkileyen faktörler
}

\author{
Gürhan Keleş*, Mert Çıbık \\ Adnan Menderes Üniversitesi, Ziraat Fakültesi, Zootekni Bölümü, Yemler ve Hayvan Besleme Anabilim Dalı, 09100 Aydın \\ *e-mail: gurhankeles@msn.com; Tel: +90 (256) 772 7024-2018; Faks: +90 (256) 7727233
}

\begin{abstract}
Özet
Mısır silajı süt sığırları rasyonların da kullanılan başlıca kaba yemdir. Bu nedenle mısır silajının kuru madde (KM) verimi (t/ha) ve besleme değerini etkileyecek faktörler işletmelerin karlılıklarını etkilemektedir. Bu çalışmada mısır silajının besleme değeri üzerine hasat zamanı, çeşit, mekanizasyon ve silaj fermantasyonunun etkileri incelenmiş ve hedeflenen bir mısır silajında bulunması gereken bazı özellikler önerilmiştir. Silajlık mısır hibritlerinde KM verimi ve besin değerinin optimizasyonu danedeki süt çizgisinin 1/2-2/3 olduğu dönemde gerçekleşirken, silolama öncesi optimum KM düzeyi \%32-36 arasında olmaktadır. Silajlık mısır hibritleri benzer danedeki süt çizgisinde silaj fermantasyonu üzerine etki edebilecek düzeyde farklı KM içermektedirler. Bu nedenle silolama amacıyla hasadın danedeki süt çizgisi ile beraber bitkinin KM içeriğine göre yapılması gerekmektedir. Hasat esnasında koçana uygulanan mekaniksel işleme ve parça uzunluğunun süt ineklerinin performansına sürekli ve belirgin etkileri bulunmamakla beraber, artan KM düzeyi ve parçalama uzunluğuna bağlı olarak koçana uygulanacak mekaniksel işlemenin önemi de artmaktadır. Silajlık mısır hibritlerinin birbirlerinden farklı besleme değerine sahip olmalarının en önemli nedeni hücre duvarı karbonhidratlarının farklı sindirilebilirlik değerlerine sahip olmasıdır. Süt veriminin artmasına paralel olarak silajlık mısır hibritlerinin performans üzerine olan etkisi daha belirgin olmaktadır. Mısır silajlarının süt ineklerinin performansı üzerine olan etkileri rasyonda kullanılan diğer kaba yem kaynaklarından da etkilenmektedir. Hedef bir mısır silajının \%31-35 arasında KM içermesi, enerji değerinin $>2.27 \mathrm{ME} \mathrm{Mcal} / \mathrm{kg} \mathrm{KM}$ 'den daha fazla olması ve 3.8-4.1 pH değerine sahip olması gerektiği değerlendirilmiştir.
\end{abstract}

Anahtar kelimeler: Besleme değeri, mısır silajı, süt ineği

\section{Factors affecting nutritive and feeding value of corn silage}

\begin{abstract}
Silage corn is a primary forage component in the ration of dairy cows. For this reason, factors affecting dry matter (DM) yield (t/ha) and feeding value of corn silage effects probability of dairy farms. This paper reviews the effect of hybrid, maturity, mechanization and fermentation on feeding value of corn silage and proposes some characteristics that target corn silage must have. The optimization between DM yield and nutritive value in corn silage hybrids occurs in 1/2-2/3 kernel milk line, while optimal DM before ensilage is \%32-36. Because of different DM content that silage hybrids have at the same kernel milk line, the ensilage must be done according to both kernel milk line and DM content of whole plant. There is no profound effect of kernel processing and chop length of corn silage on performance of dairy cows. However, importance of kernel processing increases with increasing DM of whole plant and chop length before ensilage. The differences in feeding value of corn silage hybrids result from primarily differences in digestibility of cell carbohydrates. The effect of corn silage hybrids on performance increases as milk yield of dairy cows increased. Effect of corn silage on performance of dairy cows is also affected by other source of forage used in ration. Target for good quality corn silage include a DM content of $31-35 \%$, an energy content of $>2.27$ $\mathrm{ME} \mathrm{Mcal} / \mathrm{kg} \mathrm{DM}$, and a $\mathrm{pH}$ value of 3.8-4.1.
\end{abstract}

Key words: Feeding value, corn silage, dairy cow

\section{Giriş}

Süt sığırlarının genetik kapasitelerindeki artışa paralel olarak, süt sığırı işletmelerindeki optimum verim ve karlılık büyük ölçüde besleme yönetimine dayanmaktadır. En önemli besleme uygulamalarından bir tanesi de enerji tüketimini maksimize etmektir. Dünyanın birçok ülkesinde olduğu gibi ülkemizde de süt sığırlarının beslenmesinde kullanılan en önemli kaba yem mısır silajıdır. Mısır silajının süt sığırı rasyonlarında yaygın kullanılmasının en önemli nedenleri; birim alandan yüksek KM üretme potansiyeli, bu potansiyelin güvenilir olması ve süreklilik arz etmesi, diğer kaba yem kaynaklarına kıyasla yüksek enerji değeri, süt sığırlarınca yüksek tüketim potansiyeli, toplam rasyonlarda kolayca karıştırılabilmesi, kolay silolanabilmesi, mekanizasyona uygunluğu ve önemli bir fiziksel etkili nötral 
çözücülerde çözünmeyen lif (NDF) kaynağı olmasıdır. Dolayısıyla mısır silajı enerji değeri yüksek, güvenilir bir kaba yemdir. $\mathrm{Bu}$ nedenle günümüzde süt sığırı rasyonlarının önemli bir kısmını misır silaj1 oluşturmaktadır (Fernandez ve ark., 2004; NRC, 2001).

Silajlık mısır hibritleri çoğunlukla danedeki süt çizgisine göre hasat edilmektedir. Bunun nedeni silajlık mısır hibritlerinin danelerindeki süt çizgisi ile bitki KM'si arasındaki ilişkidir (Wiersma ve ark., 1993). Bitkinin olgunlaşmasına paralel olarak bitkinin KM düzeyi de artmaktadır. Ancak danedeki benzer süt çizgisinde bitkinin içerdiği KM düzeyi farklı silajlık mısır hibritleri arasında farklı olabildiği gibi, aynı silajlık misır hibritinde yıldan yıla da değişim gösterebilmektedir (Johnson ve ark 2003a; Bagg 2007). $\mathrm{Bu}$ farklılıklar mısır silajının besin değeri ve fermantasyon özelliklerini etkileyerek silajın besleme değeri üzerine etki edebilecek düzeylere ulaşabilmektedir (Cammell ve ark 2000; Phipps ve ark 2000; Ferraretto ve Shaver 2012).

Mısır silajının içermiş olduğu enerji değerinin yaklaşık yarısı nişastadan kaynaklanmaktadır. Dolayısıyla mısır silajının içerdiği nişastanın kullanılabilirliğini artırmak yem maliyetlerinin düşürülmesi ve hayvan performansı açısından önem arz etmektedir. Mısır silajında nişasta sindirilebilirliği hasat zamanı, parçalama uzunluğu ve koçana uygulanan mekaniksel işlemden etkilenebilmektedir (Johnson ve ark 1999; Bal ve ark 2000a). Silolama esnasında bitki KM'si ve mekanizasyon arasındaki optimizasyonun sağlanamaması durumunda süt sığırlarının dışkılarında önemli miktarda bütün halde dane bulunabilmektedir (Browne ve ark 2005).

Özellikle süt yağı bakımından yüksek verimli süt sığırı rasyonlarında yüksek düzeyde kaba yem kullanımı, kaba yemlerin rumen geçiş hızının düşük olması nedeniyle KM tüketimini sınırlandıracak ve süt verimin düşmesine neden olabilecek bir uygulamadır. $\mathrm{Bu}$ bağlamda lignin içeriği düşük, NDF parçalanabilirliği yüksek silajlık mısır hibritlerinin süt ineklerinin performansları üzerine olumlu etkileri belirlenmektedir (Gençoglu ve ark 2008). Ayrica rumen fermantasyonu rasyonda farklı silajlık mısır hibritleri kullanımından da etkilenmektedir (Johnson ve ark 2002a). Bu nedenle sindirilebilirliği yüksek çeşitlerin seçimi ile KM tüketiminin artırılarak, rasyonda daha fazla oranda kaba yem kullanımına olanak sağlanabilir. Rasyonda daha yüksek kaba yem kullanımı ile optimum rumen $\mathrm{pH}$ 's1 temin edilerek metabolik rahatsızlıkların önüne geçilme şansıda artar. Kaba yemlerin içermiş oldukları hücre duvarı bileşenleri (lif) kaba yemlerdeki fiziksel etkili NDF'nin ana kaynağı olup ruminasyon, rumen $\mathrm{pH}$ 's1 ve süt yağı ile yakından ilişkilidir. Mısır silajının süt sığırı rasyonlarında kullanılan temel kaba yem olmasindan dolayı, içermiş olduğu NDF'nin etkinliğini etkileyebilecek çeşit, parçalama uzunluğu ve mekaniksel işleme gibi faktörlerin büyük önemi bulunmaktadır (Mertens, 1997; Kung ve ark 2008; Ferraretto ve Shaver 2012).

$\mathrm{Bu}$ çalışmada mısır silajının besleme değerine etki edebilecek hasat zamanı, hibrit çeşidi, silaj fermantasyonu, koçana uygulanan mekaniksel işleme ve parça büyüklüğü gibi faktörler incelenmiştir. Ayrıca, besleme değeri yüksek misır silajlarının elde edilebilmesi için bazı tespitler yapılmış ve üretilmesi hedeflenen kaliteli bir misır silajında bulunması gereken bazı fermantasyon, besin maddesi ve enerji değerlerinin en az ve en yüksek değerleri önerilmiştir.

\section{Hasat Zamanı}

\section{Kuru madde düzeyi}

Silajlık mısır hibritlerinin silolama amacıyla biçim zamanın belirlenmesinde bitkinin $\mathrm{KM}$ düzeyi, $\mathrm{KM}$ verimi ( $t / d a)$, enerji içeriği ve sindirilebilirlik parametrelerinin optimizasyonu hedeflenir. Bu nedenle hasat zamanındaki zamanlama mısır bitkisi için oldukça önemlidir.

Danedeki $1 / 3$ ve $2 / 3$ süt çizgisinde; Johnson ve ark (2003) aynı silajlı hibritin (Zea mays indurata) 1. yll sirasiyla, $\% 26.8$ ve $30.2 ; 2$. y1l $\% 27.9$ ve 33.3 , farklı bir silajl1k hibritin (Zea mays indendata) $\% 28.3$ ve 35.6; Filya (2004) ise \%28.2 ve $35.8 \mathrm{KM}$ içerdiğini belirlemişlerdir. Bagg (2007) danedeki süt çizgisinin 1/2 olduğu dönemde silajlı mısır hibritlerinin iklim koşulları ve silajlık mısır çeşidine bağlı olarak \%28-48 arasında $\mathrm{KM}$ içerebileceğini bildirmektedir. Bunun en önemli nedeni dane verimi yüksek silajlık mısır hibritlerinde danenin olgunlaşması esnasında diğer bitki kısımlarının yeşil kalması, buna karşın sadece silajlık amaçlı yetiştirilen hibritlerde ise genel olarak koçanda danenin olgunlaşması esnasında diğer bitki kısımlarının daha hızlı kurumasıdır. Dolayısı ile sadece silajlık amaçlı üretilmiş mısır hibritlerinde danedeki süt çizgisi diğer silajlık mısır hibritlerine kıyasla daha az güvenilir olmaktadır. Bu nedenle silajlı amacıyla yetiştirilecek mısır hibritinde danedeki süt çizgisi ile bitki KM'si arasındaki ilişkinin bilinmesi önem taşımaktadır. Danedeki süt çizgisi ve bitki KM'si arasındaki varyasyondan dolayı oluşabilecek düşük $\mathrm{KM}$ verimi, besleme değeri ve olumsuz silaj fermantasyonun 
Çizelge 1. Erken gelişen 4 silajlı mısır hibritinin KM verimleri ve besin değerleri ${ }^{1}$

\begin{tabular}{lcccccc}
\hline Hasat zamanı & KM, $\%$ & KMV, kg/da & HP, $\%$ & NDF, $\%$ & ADF, $\%$ & KMS, \% \\
\hline Dişlenme & 24 & 1.81 & 10.3 & 53 & 27 & 77 \\
Erken dişlenme & 27 & 1.87 & 9.9 & 48 & 24 & 79 \\
1/2 süt çizgisi & 34 & 2.11 & 9.2 & 45 & 23 & 80 \\
3/4 süt çizgisi & 37 & 2.14 & 8.9 & 47 & 24 & 80 \\
Siyah katman & 40 & 2.11 & 8.4 & 47 & 24 & 79 \\
\hline
\end{tabular}

${ }^{1}$ KMV: KM verimi; HP=Ham protein; NDF=Nötr deterjan lif; ADF= Asit deterjan lif; KMS=İn-vitro KM sindirilebilirliği

önlenmesi için pratik koşullarda yapılacak en kolay yöntem danede \%10-15 süt çizgisi oluşmaya başlayınca, tarlanın örneklenerek KM'nin belirlenmesidir. Çünkü iklimin ekstrem olmadığ 1 yıllarda danede süt çizgisinin oluşmasının ardından bitkinin KM'si günlük 0.5-0.75 birim artmaktadır. Bu nedenle bitki örneklendiği zaman $\mathrm{KM} \% 30$ ise ve $\% 35 \mathrm{KM}$ düzeyinde hasat öngörülüyorsa, hasadın bitkinin örneklendiği günden 710 gün sonra yapılması gerekmektedir. Hasat zamanın tahmin edilmesinde kullanılacak diğer bir yöntem bitkinin püsküllenme/çiçeklenme döneminin belirlenmesidir. Silajlık misır hibritleri genel olarak bu dönemden ortalama 45 gün sonra $\% 30 \mathrm{KM}$ düzeyine ulaşmaktadır (Cox, 2008). Ancak bu sürenin kurak yıllarda 34-35 güne kadar düşebileceği de belirtilmektedir. Dolayısıyla iklimin normal olduğu y1llarda bu yöntemlerin farklı tarlalardaki silajlık misırların hangisinin daha önce hasat edilmesine karar verilirken kullanılması daha doğru olacaktır.

\section{Verim ve besin değeri}

Çizelge 1'de erken gelişen (85 gün) 4 farklı silajlık mısır hibritleriyle 3 yıl yapılan çalışmada hibritlerin farklı gelişme dönemlerindeki (danedeki süt çizgisi) $\mathrm{KM}$ verimleri $(\mathrm{t} / \mathrm{da})$ ve besin değerleri (Wiersma ve ark 1993); Çizelge 2'de ise 110 gün silajlık hasat olgunluğuna sahip bir çeşidin farklı gelişme dönemlerindeki besin değeri (Bal ve ark., 1997) verilmiştir. Çizelge 1 ve 2 incelendiğinde kısa ve uzun süreli hasat olgunluğuna sahip silajlık mısır hibritlerinde hücre duvarı karbonhidratlarının erken dişlenmeden süt çizgisinin danede $2 / 3$ oranına ulaşınca kadar düştügünü buna karşın nişasta içeriğinin arttığ görülmektedir. Benzer şekilde Johnson ve ark. (2002b)'da danede 1/3, $2 / 3$ süt çizgisi ve siyah katmanda hasat edilen 3 farklı çeşidin NDF içeriğinin $1 / 3$ süt çizgisinden $2 / 3$ süt çizgine kadar düştüğünü, ancak siyah katman oluşumuna doğru yeniden arttığını, buna karşın nişasta ve lif olmayan karbonhidrat içeriğinin NDF'nin tam tersine değiştiğini bildirmişlerdir. Mısır silajının içerdiği karbonhidratlardaki değişime paralel olarak KM sindirilebilirliği de siyah katman oluşumuna kadar değişmezken, siyah katman döneminde en düşük olmaktadır. Nişasta sindirilebilirliği ise bitki gelişimine paralel olarak düşmekte, ancak danedeki süt çizgisinin $1 / 4$ ve $1 / 2$ olduğu dönemde değişmemektedir (Çizelge 2).

Dört farklı silajlık mısır hibritinin 3 yıllık ortalama KM verimleri incelendiğinde (Çizelge 1), birim alandan üretilen $\mathrm{KM}$ veriminin ( $\mathrm{t} / \mathrm{da}$ ) danedeki süt çizgisinin $1 / 2$ ve bitkinin KM düzeyinin \%34 olduğu döneme kadar arttığı görülmektedir. Khan ve ark. (2012)'da \%30, 34, 40 ve $42 \mathrm{KM}$ içeren silajlık misırda $\mathrm{KM}$ veriminin sirasiyla, $1.63,1.73,1.70$ ve $1.71 \mathrm{t} / \mathrm{da}$ olduğunu bildirmektedir. $\mathrm{Bu}$ nedenle gerek besin değeri ve gerekse KM verimi dikkate alındığında silajlık mısır hibritlerinin silolama amacıyla hasadının bu dönemde yapılması gerekliliği ortaya çıkmaktadır. Ancak danedeki süt çizgisine göre yapılacak hasatta bitkinin $\mathrm{KM}$ içeriğinin y1l, mevsim ve hibrit çeşidine göre farklılık göstermesinden dolayı hem danedeki süt çizgisi hem de bitkinin içermiş olduğu KM düzeyinin birlikte ele alınması gerekmektedir.

Çizelge 2. Hasat zamanı 110 gün olan bir çeşidin besin değeri ${ }^{1}$

\begin{tabular}{lcccccccc}
\hline Hasat zaman1 & KM, \% & HP, \% & NDF, \% & ADF, \% & Lignin, \% & Nişasta, \% & KMS, \% & NS, \% \\
\hline Erken dişlenme & 30 & 7.5 & 52 & 32 & 3.3 & 18 & $62 \mathrm{a}$ & $94 \mathrm{a}$ \\
1/4 süt çizgisi & 32 & 7.3 & 44 & 27 & 2.8 & 29 & $62 \mathrm{a}$ & $93 \mathrm{ab}$ \\
2/3 süt çizgisi & 35 & 7.1 & 41 & 24 & 2.9 & 37 & $61 \mathrm{a}$ & $92 \mathrm{~b}$ \\
Siyah katman & 42 & 7.0 & 41 & 24 & 2.7 & 37 & $59 \mathrm{~b}$ & $88 \mathrm{c}$ \\
\hline
\end{tabular}

${ }^{1}$ Aynı sütünda farklı harflerle gösterilen ortalamalar arasındaki farklılıklar önemlidir $(\mathrm{P}<0.05)$. Sadece KMS ve NS değerlerine varyans analizi uygulanmış. $\mathrm{HP}=\mathrm{Ham}$ protein; $\mathrm{NDF}=\mathrm{Nötr}$ deterjan lif; $\mathrm{ADF}=$ Asit deterjan lif; KMS: KM sindirilebilirliği; NS: Nişasta sindirilebilirliği 
Çizelge 3. Mısır silajının KM düzeyinin süt ineklerinin performansına etkisi ${ }^{1}$

\begin{tabular}{|c|c|c|c|c|c|c|c|c|c|}
\hline $\mathrm{KM}, \%$ & $\mathrm{n}$ & $\mathrm{KMT}, \mathrm{kg} / \mathrm{g}$ & KMS, \% & NS & $\mathrm{SV}, \mathrm{kg} / \mathrm{g}$ & DSV, $\mathrm{kg} / \mathrm{g}$ & Yağ, \% & Protein, $\%$ & SÜN, mg/dl \\
\hline$<28.0$ & 5 & 24.2 & 66.3 & $93.2 \mathrm{ab}$ & $36.1 \mathrm{ab}$ & $33.5 \mathrm{abc}$ & 3.58 & 3.05 & 13.5 \\
\hline $28.1-32.0$ & 19 & 23.6 & 66.0 & $94.0 \mathrm{a}$ & $37.3 \mathrm{a}$ & $34.7 \mathrm{a}$ & 3.59 & 3.07 & 13.6 \\
\hline $32.1-36.0$ & 35 & 24.1 & 66.2 & $92.1 b c$ & $33.5 \mathrm{ab}$ & $33.5 \mathrm{ab}$ & 3.51 & 3.11 & 13.5 \\
\hline $36.1-40.0$ & 30 & 23.8 & 67.6 & $93.4 \mathrm{ab}$ & $33.0 \mathrm{~b}$ & $33.0 \mathrm{~b}$ & 3.45 & 3.10 & 13.5 \\
\hline$>40.0$ & 16 & 24.1 & 67.5 & $91.3 \mathrm{c}$ & $31.0 \mathrm{c}$ & $31.0 \mathrm{c}$ & 3.42 & 3.10 & 13.8 \\
\hline
\end{tabular}

\section{Hayvan performanst}

Silajlık mısır hibritlerinin hasat zamanının hayvan performansı üzerine olan etkilerinin değerlendirildiği derleme çalışmasında (Johnson ve ark., 1999) danedeki süt çizgisinin $\% 12.5,25,50,66$ ve 100 olduğu dönemde hasat edilerek silolanmış mısır silajlarıyla beslenen süt ineklerinden en yüksek süt veriminin $\% 50$ ve 66 süt çizgisinde silolanan silajlarla beslenen ineklerden alındığı bildirilmiştir. Aynı araştırıcılar incelenen literatürler arasında en yüksek süt verimi ve $\mathrm{KM}$ tüketiminin \%33-36 KM içeren misır silajlarıyla beslenen ineklerde olduğunu bildirmişlerdir. Ancak eski literatür bildirişlerine dayanarak belirlenen bu derleme sonuçlarının süt verimi düşük ineklerle yapıldığı da bildirilmiştir. Ferraretto ve Shaver (2012)'in farklı düzeylerde $\mathrm{KM}$ içeren misır silajlarıyla yapılan araştırmalara dayanarak yaptıkları meta-analiz sonuçları Çizelge 3'de verilmiştir. Çizelge 3 incelendiğinde farklı düzeylerde $\mathrm{KM}$ içeren mısır silajlarıyla beslenen süt ineklerinin KM tüketimleri, sütlerindeki yağ ve protein oranları ve süt üre-N'nun mısır silajının KM düzeyinden etkilenmediği görülmektedir. Siyah katman döneminde (>\%40 KM) silolanan silajlarla beslenen süt sığırları diğer olgunluk dönemlerindeki silajlarla beslenen süt sığırlarından daha düşük $(\mathrm{P}<0.05)$ süt ve $\% 4$ yağlı süt üretmişlerdir. $\mathrm{Bu}$ durum $\% 40 \mathrm{KM}$ düzeyinden daha yüksek silajların düşük nişasta sindirilebilirliği $(\mathrm{P}<0.05)$ ile açıklanabilir. Çalışmada ayrıca \%28-32 arasında KM içeren silajlarla beslenen inekler, \%36-40 arasında KM içeren silajlarla beslenen ineklerden $1.7 \mathrm{~kg} /$ gün daha fazla $(\mathrm{P}<0.05)$ düzeltilmiş süt üretmişlerdir. $\mathrm{Bu}$ sonuçlar mısır silajının $\mathrm{KM}$ düzeylerinin $\% 36$ 'den daha fazla olması durumunda verimin olumsuz etkilenebileceğini göstermektedir.

$1 / 3$ ve $2 / 3$ danedeki süt çizgisinde silolanan mısır silajlarının KM'sinin taze materyalin KM'sinden Johnson ve ark. (2003) yaklaşık olarak \%4, Filya (2004) ise $\% 3$ daha düşük olduğunu bildirmişlerdir. Dolayısıyla genel olarak silajların KM düzeyleri silolandığı andaki KM düzeylerinden yaklaşık olarak en az 1 birim düşük olmakta ve bu değer silolanan materyalin KM düzeyi arttıkça düş̧mektedir. Bu nedenle Çizelge 3'de \%36-40 arasında $\mathrm{KM}$ içeren silajlar yaklaşık olarak en az \%37 olmak üzere \%37-41 arasında KM içerdikleri dönemde silolanmışlardır. Çizelgede dikkat çekici diğer konu $\% 28$ 'den daha düşük KM içeren silajlarla beslenen ineklerin verim parametrelerinin de oldukça tatminkar olmasıdır. Halbuki bu dönemde bitki daha yüksek hücre duvarı bileşenlerine sahiptir (Çizelge 1 ve 2). Bu durum hayvan performansı üzerine misır hibritlerinin oransal olarak içermiş oldukları NDF miktarının değil NDF'nin sindirilebilirliğinin daha önemli olduğunu ortaya koymaktadır (Holt ve ark., 2013).

\section{Çeşit}

Silajlık amacıyla kullanılacak hibrit misırların farklı besin değerlerine sahip olması bu silajlarla beslenen süt sığırlarının KM tüketimleri ve süt verimlerini etkileyebilmektedir (Andrea ve ark., 2001; Holt ve ark., 2013). Silajlık misır hibritlerinden kahverengi yaprak damarlı (KYD) çeşitler diğer silajlı mısır hibritlerinden farklı bazı özellikleri ile öne çıkmıştır. Bu çeşitlerle yapılan 11 araştırmanın sonuçlarını kapsayan meta analiz sonuçları (Gençoğlu ve ark., 2008) Çizelge 4'de verilmiştir. Çizelge incelendiğinde KYD ve diğer hibrit

Çizelge 4. Kahverengi yaprak damarlı silajların besin ve besleme değerleri ${ }^{1}$

\begin{tabular}{lcccccccc}
\hline Silaj $^{2}$ & KM, \% & Nişasta, \% & NDF, \% & IVNDFS, \% & KMT, kg/g & SV, kg/g & Yağ, kg/g & Protein, kg/g \\
\hline Kontrol & 33.5 & 30.5 & 42.0 & 46.1 & $24.2 \mathrm{~b}$ & $37.7 \mathrm{~b}$ & $1.36 \mathrm{~b}$ & $1.15 \mathrm{~b}$ \\
Kahverengi D. & 32.5 & 29.9 & 40.9 & 57.6 & $25.4 \mathrm{a}$ & $39.4 \mathrm{a}$ & $1.40 \mathrm{a}$ & $1.20 \mathrm{a}$ \\
\hline
\end{tabular}

${ }^{1}$ IVNDFS=In-vitro NDF sindirilebilirliği; KMT=KM tüketimi; KMS=KM sindirilebilirliği; SV=Süt verimi

2: Aynı sütünda farklı harflerle gösterilen ortalamalar arasındaki farklılıklar önemlidir $(\mathrm{P}<0.05)$. Sadece KMT, SV, Süt yağı ve proteini arasında meta analiz yapılmış. 
silajların NDF içerikleri birbirlerine çok yakın olduğu halde, KYD silajların in-vitro NFD sindirilebilirlikleri $\% 25$ daha fazla bulunmustur. NDF sindirilebilirliğindeki bu önemli artış sonucunda KYD silajlarla beslenen inekler $1.2 \mathrm{~kg}$ daha fazla $\mathrm{KM}$ tüketmişler ve $1.7 \mathrm{~kg} /$ gün daha fazla süt ve $50 \mathrm{~g} / \mathrm{gün}$ daha fazla protein üretmişlerdir. Kahverengi yaprak damarlı silajlık mısır hibritlerindeki yüksek NDF sindirilebilirliği bu hibritlerin düşük lignin içeriklerinden kaynaklanmaktadır. Ancak bütün çalışmalarda KYD silajlarla beslenen süt sığırlarının performanslarında artışlar gözlenmemiştir. Holt ve ark. (2013), KYD ve ticari silajlık hibritlerle yaptıkları çalışmada laktasyonun ilk 60 günlük periyodunda KYD misir silaji ile ticari hibrit misir silajiyla beslenen ineklerin performanslarında bir farklılık $(\mathrm{P}<0.05)$ belirlememişler, ancak laktasyonunun 61-180. günleri arasında KYD misır silajıyla beslenen inekler $1.1 \mathrm{~kg} / \mathrm{g}$ daha fazla KM tüketme eğilimine $(\mathrm{P}=0.07)$ sahip olmuşlar ve $1.2 \mathrm{~kg} / \mathrm{g}$ daha fazla süt üretmişlerdir. Benzer şekilde Holt ve ark. (2010) KYD ve konvansiyonel misir silajıyla beslenen ineklerle yaptıkları çalışmada iki faklı mısır silajını 2x2 faktöriyel deneme planında rasyon KM'sinde \%26 yonca kuru otu ve $\% 31$ misir silaj ya da $\% 23.6$ yonca kuru otu ve $\% 25$ mısır silaj1 içeren rasyonlarla beslemişlerdir. Her iki rasyonun NDF'ni eşitlemek için kaba yem yerine soya kabuğu ve pancar posası ilave etmişlerdir. Araştırma sonucunda çeşit farklılığının ineklerin KM tüketimleri üzerine etkisi bulunmazken $\% 3.5$ yağlı süt verimi ve süt yağı yüzdesi KYD silajıyla beslenen ineklerde daha düşük belirlenmiştir. Bu çalışmada KYD silajının NDF parçalanabilirliği diğer hibrit çeşidinden \%26 daha yüksek olmasına rağmen toplam rasyondaki NDF $(\mathrm{P}=14)$ ve asit deterjanda çözünmeyen lif (ADF)'nin $(\mathrm{P}=0.06)$ in-vivo sindirilebilirliği ticari hibrit silajı içeren rasyonda daha yüksek olma eğilimi göstermiştir. Bu iki çalışma (Holt ve ark., 2010, 2013) sonuçları mısır silajın süt ineklerinin performansına olan etkilerin diğer rasyon unsurlarından etkilenebileceği ve özellikle rasyonda artan kaba yem düzeyi ve süt verimine paralel olarak kaba yem kalitesinin etkilerinin daha fazla önem kazandığını göstermektedir.

Ballard ve ark. (2001) yapraklı ve KYD ile dane ve silajlık yetiştirilebilen silajlık mısır hibritlerinin besleme değerini karşılaştırmışlardır. Çalışmada dane verimi yüksek çeşitle beslenen düvelerin KM tüketimi diğer iki çeşitten daha düşük belirlenmiş, ancak süt ineklerinin süt verimi yapraklı çeşitten farklı olmamıştır. Çalışmada en yüksek süt verimi KYD misır silajıyla beslenen ineklerden alınmıştır. Bal ve ark. (2000b) yaptıkları 3 çalışmanın ilkinde düşük ve yüksek bitki yoğunluğunda ekilmiş konvansiyonel ve yapraklı silajlık hibrit mısırları 1/2 süt çizgisinde; ikincisinde konvansiyonel silajlık misır hibrit ve KYD silajlık misır hibritini 1/2 süt çizginde; üçüncüsünde ise normal NDF (\%39) ve düşük NDF (\%33) içeren 2 farklı silajlık mısır hibritini sırasıyla $1 / 3$ ve $1 / 2$ süt çizgisinde hasat ederek silolamışlardır. Silajların KM içerikleri ilk denemede $\% 32-36$ arasında, ikincide $\% 34.3$ ve 32.2 , üçüncüde denemede $\% 37$ ve 34 olarak belirlenmiştir. İlk ve ikinci denemede süt ineklerinin KM tüketimleri ve düzeltilmiş süt verimleri silajlardan etkilenmemiştir. Üçüncü denemede \%39 NDF'li silaj içeren rasyonların yüksek sindirilebilirlik parametreleri ineklerin KM tüketimini artırmıştır. Yağ içeriği yüksek bir çeşitle normal bir silajlık mısır hibritin karşılaştırıldığı diğer bir çalışmada (Weiss ve Wyatt 2000) ise yağ içeriği yüksek silaj düzeltilmiş süt verimini artırmıştır (23.9'e 22.6).

Mısır silajının enerji değerinin yaklaşık yarısının nişasta kaynaklı olması silajlık mısırların içerdiği nişasta özelliklerini önemli kılmaktadır. At dişi (Zea Mays indendata) ve sert (Zea Mays indurate) misir danelerinin nişasta özellikleri birbirlerinden farklılık göstermektedir. At dişi mısırlar daha fazla oranda çiçeksi yapıda bir endosperme sahipken, sert mısırlar daha fazla oranda camsı yapıda bir endosperme sahiptirler. Camsı endospermde nişasta granüllerinin proteinle çevrili olması ve bir matrix içerisinde bulunması nişastanın sindirimini sınırlamaktadır. Dolayısıyla at dişi danelerin rumen nişasta sindirilebilirlikleri sert mısır danelerinden daha yüksek olmaktadır. Danedeki camsız yapının azaltılmasına yönelik yapılacak genetik seleksiyonların nişastanın ruminal ve post-ruminal sindirilebilirliğini maksimize etmek için kullanılabileceği önerilmektedir (Johnson ve ark 1999). Nişastanın rumende mikrobiyal sindirime uğramasıyla oluşacak enerji kayıpları ve yüksek verimli süt ineklerinin özellikle erken laktasyondaki yüksek enerji ihtiyaçları (NRC, 2001) düşünüldüğünde mısır danesinde oransal olarak rumen parçalanabilirliği düşük ancak post-ruminal sindirilebilirliği yüksek camsı endosperm oranının daha yüksek olması gerektiği düşünülebilir. Ancak, Andrea ve ark. (2001), sert ve yumuşak dane yapısına sahip iki silajlık mısır silajıyla 2 farklı hasat zamanında (1/2 süt çizgisi ve siyah katman), yaptıkları çalışmada danelerinde camsılık bulunan silajdaki nişasta sindirilebilirliğinin bitki olgunlaşmasıyla düştüğünü bildirmişlerdir. 


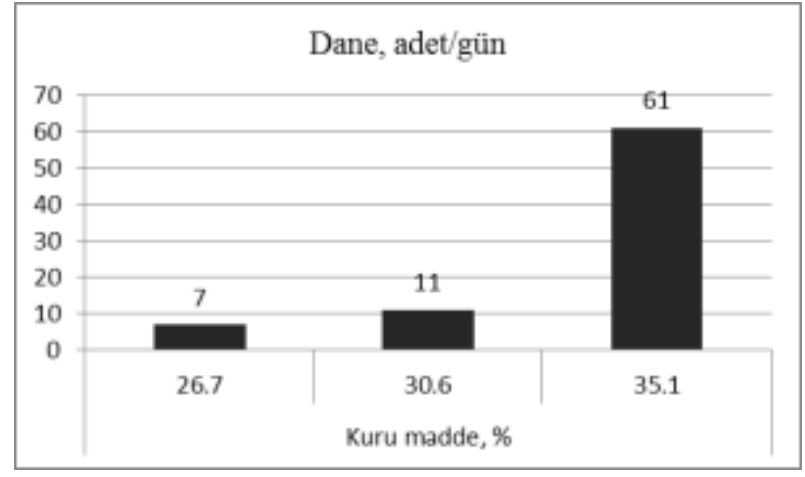

Şekil 1. Farklı KM düzeylerinin dışkıdaki dane sayısına etkisi (adet/gün).

\section{Mekanizasyon}

\section{Koçana uygulanan mekanik işleme}

Mekaniksel işleme mısır ve buğdaygil otlarında uygulanan bir işlem olup amacı silaj makinasına monteli ekipmanlarla hasat esnasında koçanı ezmek ya da zedelemek suretiyle danenin kullanılabilirliğini artırmaktır. Tam aktif işleyiciler, hasat makinasının biçme ve üfleme kısımları arasında bıçaklara paralel olarak yer alan 2 silindirden oluşmaktadır. Silindirler tırtıklı ve yakın aralıklı ve farklı hızlarda çalışmaktadır. Koçanın işlenmesi ezme ve zedeleme şeklinde yapılmaktadır. Silindir açıklıkları 1-5 mm, hız oranı $\% 5-60$, çap1 150-300 mm olup, $1-4$ oluk $/ \mathrm{cm}$ içermektedirler. Silindirlerin açıklıkları ayarlanabilmektedir. Silaj hasat makinalarındaki mekaniksel işleme ünitesi ilave enerji gerektirmekte ve makinanın iş kapasitesini düşürmektedir. Koçana hasat esnasında uygulanan mekaniksel işleme mısır silajı için silaj makinasının iş kapasitesini \%0-28 azaltmakta, belirli bir enerjiye olan ihtiyacı \%7-15 artırmaktadır (Johnson ve ark. 1999).

Mısır silajının hasadının danede nişasta birikiminden sonra yapılması dolayısıyla ergin sığırlarda mısır danelerin sindirimi düşmektedir. Şekil 1'de 3 farklı KM içeren mısır silajı ile beslenen danalardan elde edilen gübrelerdeki bütün haldeki dane sayısı verilmiştir
(Browne ve ark 2005). Şekilden de görüldüğü gibi hasat zamanındaki gecikme ile dışkıdaki bütün haldeki dane sayısı artmıştır. Dışkıdaki adet olarak sayılan dane sayıs1 yedirilen dane sayısının artan KM ile sirasıly $\% 18,2.4$ ve 15 'ine tekabül etmektedir. Dışkıdaki dane miktarındaki bu artış sonrası silajların ME içerikleri artan silaj KM'si ile sirasiyla 11.0, 11.1 ve $10.6 \mathrm{MJ} / \mathrm{kg}$ $\mathrm{KM}$ olarak hesaplanmıştır. Bu çalışmanın besi başı canlı ağırlıkları $352 \mathrm{~kg}$ ve KM tüketimleri 8.3-9.2 kg/gün olan besi danalarıyla yapıldığg düşünüldüğg̈nde canlı ağırlıkları $600 \mathrm{~kg}$ 'ın, günlük $\mathrm{KM}$ tüketimleri ise 20 kg'ın üzerinde olan yüksek verimli süt sığırlarında daha büyük önem arz edecektir. Dolayısı ile koçana uygulanan mekaniksel işleme sonucunda misır danelerinin ve koçanın tamamının silolamadan önce parçalanması ya da ezilmesinin rumende mikroorganizmaların fermantasyonuna bitki unsurlarını daha açık hale getirerek rumende parçalanabilirliği, alt sindirim organlarında ise enzimatik sindirimi artırarak silajın besin değerini artırması beklenebilir. Nitekim Shinners ve ark. (2000) koçana mekaniksel işlem uygulanmamış silajlarda \%50 olan kırılmış ya da ezilmiş dane miktarının mekaniksel işleme ile \%100'e yakın olduğunu, Ferraretti ve Shaver (2012) ise mekaniksel işleme ile tüm koçanın sindirilebilirliğinin \%58 arttığını bildirmiştir. Bununla beraber, yapılan bazı çalışmalarda mekaniksel işlemenin mısır silajının KM sindirilebilirliğine ve sonuçta hayvan performansı üzerine muhtemel olumlu etkilerine yönelik tutarlı bir etki belirlenmemiştir. Dhiman ve ark (2002), danede 1/4-3/4 süt çizgisinde silolanan mısır silajında mekaniksel işlemenin etkisinin araştırıldığı üç çalışmanın sadece bir tanesinde süt ineklerinin $\mathrm{KM}$ tüketimlerinde $1.2 \mathrm{~kg} / \mathrm{gün}$ artış belirlemişler ancak bu artış ineklerin süt verimine yansımamıştır $(\mathrm{P}>0.05)$. Bu üç çalışmanın ikisinde nişasta sindirilebilirliği ve bir çalışmada KM tüketimi artırmasına rağmen mekaniksel işlemenin laktasyondaki süt ineklerinin performansına olan etkisinin düşük olduğu belirlenmiştir. Ferraretti ve Shaver (2012) tarafindan silolamadan hemen önce

Çizelge 5. Farklı parçalama uzunluğuna sahip mısır silajlarında koçana uygulanan mekaniksel işlemenin süt ineklerinin performansı üzerine etkileri ${ }^{1}$

\begin{tabular}{lccccccccc}
\hline & $\mathrm{n}$ & $\mathrm{KMT}, \mathrm{Kg} / \mathrm{g}$ & $\mathrm{KMS}, \%$ & $\mathrm{NS}$ & $\mathrm{SV}, \mathrm{kg} / \mathrm{g}$ & $\mathrm{DSV}, \mathrm{kg} / \mathrm{g}$ & $\mathrm{Yag}, \%$ & Protein, \% & $\mathrm{SÜN}, \mathrm{mg} / \mathrm{dl}$ \\
\hline İşlenmiş & & & & & & & & & \\
$1-3 \mathrm{~mm}$ & 43 & 23.9 & 67.2 & $94.8 \mathrm{a}$ & 36.6 & 33.2 & $3.4 \mathrm{~b}$ & 3.10 & $13.3 \mathrm{~b}$ \\
$4-8 \mathrm{~mm}$ & 7 & 23.3 & 66.2 & $88.9 \mathrm{c}$ & 34.6 & 31.5 & $3.4 \mathrm{ab}$ & 3.05 & $13.4 \mathrm{ab}$ \\
İşlenmemiş & 58 & 24.0 & 66.4 & $92.0 \mathrm{~b}$ & 36.2 & 33.4 & $3.5 \mathrm{a}$ & 3.10 & $13.8 \mathrm{a}$ \\
\hline
\end{tabular}

${ }^{1}$ Aynı sütünda farklı harflerle gösterilen ortalamalar arasındaki farklılıklar önemlidir $(\mathrm{P}<0.05)$.

$\mathrm{KMT}=\mathrm{KM}$ tüketimi; KMS=KM sindirilebilirliği; NS=Nişasta sindirilebilirliği; SV=Süt verimi; DSV=Düzeltilmiş süt verimi (\%4); SÜN=Süt üre-N 
koçana uygulanan mekaniksel işlemenin farklı parçalama uzunluğuna sahip misır silajlarının besin değeri ve hayvan performansı üzerine olan etkilerin incelendiği çalışmaları kapsayan meta analiz sonuçları Çizelge 5'de verilmiştir.

Çizelge 5 incelendiğinde farklı parçalama uzunluğuna sahip silajlarda mekaniksel işleminin mısır silajının besin ve besleme değeri üzerine belirgin bir etkisi olmadığ1 görülmektedir. Özellikle düşük parça uzunluğuna sahip silajlarda mekaniksel işleme süt yağını düşürmüştür. Bu durum düşük parça uzunluğuna sahip misır hibritlerine silolama öncesi ayrıca uygulanan mekaniksel işleme ile rumen geçiş hızının artması sonucunda düşen geviş getirme ile alakalı düşük tükürük salgısı ve düşük rumen $\mathrm{pH}$ 'nı düşündürmektedir. Çünkü mekaniksel işleme silajların NFD sindirilebilirliklerini aynı veri setinde \%2 artırmış olmasına rağmen işlenmemiş silajlara kıyasla ineklerin KM tüketimleri değişmemiştir. Schwab ve ark (2002) da mekaniksel işlemenin farklı parçalama uzunluğuna sahip mısır silajıyla beslenen sığırların süt yağını düşürdüğünü ancak Bal ve ark (2000a) tarafından bildirilen değerlere benzer şekilde geviş getirme (dak/gün) zamanını etkilemediğini belirlemişlerdir. Mekaniksel işlemenin mısır silajlarının besin değerine en önemli etkisi nişasta sindirilebilirliğinde gözlenmiş, \%32-40 arasında KM içeren silajlarda silolama öncesi uygulanan mekaniksel işleme nişasta sindirilebilirliğini artırmıştır (Ferraretto ve Shaver 2012). Mekaniksel işleme sonucu elde edilen düşük süt üre-N'i artan nişasta sindirilebilirliğine bağlı olarak, rumende N'in daha etkin kullanıldığını göstermektedir. Bu sonuçların aksine mekaniksel işlemenin süt ineklerin performansina olan olumlu etkileri Bal ve ark (2000a) tarafından bildirilmiştir. Araştırıcılar, 0.95-1.90 cm uzunluğunda parçalanmış silajlara uygulanan mekaniksel işleminin $\mathrm{KM}$ tüketimi, süt verimi ve süt yağı yüzdesini sırasıyla, $\% 2.4,2.7$ ve 5 artırdığını bildirmişlerdir.

\section{Silolama öncesi parça uzunluğu}

Silolama öncesi parça uzunluğunun mısır silajlarının besleme değeri üzerine olan etkileri ile yapılan kapsamlı çalışmalarda da parçalama uzunluğunun süt ineklerinin performansları üzerine belirgin etkileri belirlenmemiştir (Bal ve ark 2000a; Schwab ve ark 2002). Ferraretto ve Shaver (2012) 106 çalışmaya dayalı yaptıkları meta analizde $0.48->3.2 \mathrm{~cm}$ boyutlarında parçalanan mısır silajlarının hayvanların performansları üzerine olumlu ya da olumsuz etkilerinin bulunmadı̆̆ını bildirmişlerdir. Bununla beraber bu çalışmalarda kullanılan rasyonların büyük çoğunluğunda mısır silajı ile beraber yonca silajı, yonca kuru otu, buğdaygil otları gibi parça uzunluğu misır silajından yüksek otlarda kullanılmıştır. Örneğin parça büyüklüğünün önemsiz bulunduğu iki çalışmada (Bal ve ark 2000b ve Schwab ve ark 2002) misir silaj1 ile beraber kullanılan yonca silajı rasyon KM'sinin sırasıyla \%16.4 ve 20'sini oluşturmuştur. Bu nedenle mısır silajının parça uzunluğunun rasyonun bileşimde kullanılan diğer kaba yem kaynaklarının özelliklerine göre hayvan performansına etki edebileceği göz önünde bulundurulmalıdır. Çünkü yapılan çalışmalarda rasyonda kullanılan diğer kaba yem kaynaklarının etkileri yeterince belirlenmemiştir. Nitekim, farklı silajlık mısır hibritlerinden oluşmuş rasyonlara katılan sindirilebilirliği yüksek farklı kaba yem kaynakları rumen $\mathrm{pH}$ 'sını ve asetik asitin molar miktarını artırdı ğ belirlenmiştir (Castro, 2010).

\section{Fermantasyon özellikleri}

Misır bitkisini silolamadaki zamanlama sadece elde edilecek KM verimi ve besin değeri arasındaki sekronizasyon açısından değil, aynı zamanda elde edilecek silajın kalitesi bakımından da önem arz etmektedir. Çünkü fermantasyon kalitesi süt sığırlarının KM tüketimlerini etkileyerek mısır silajlarının besleme değerini düşürebilmektedir. Farklı silajlık mısır hibritlerinin farklı gelişme dönemlerinde içerdiği şeker miktarları Çizelge 6'de verilmiştir. Çizelgeden de görüldüğü farklı silajlık mısır hibritlerinin içermiş oldukları suda çözünebilir karbonhidrat miktarları bitki gelişiminin artmasına bağlı olarak düşmektedir. Katkı maddesi içermeyen çayır silajlarıyla yapılmış 33 çalışmanın sonuçlarının değerlendirildiği bir çalışmada (Haigh ve Parker 1985), başarılı bir silaj fermantasyonu için silajlık materyalde bulunması gereken suda

Çizelge 6. Farklı gelişme dönemlerinin silajlık mısır hibritlerinin şeker içeriklerine etkisi (\%)

\begin{tabular}{|c|c|c|c|c|}
\hline Çalışma & Erken dişlenme & $1 / 3$ süt & $2 / 3$ süt & Siyah katman \\
\hline Filya, 2004 & 9.7 & 7.8 & 5.5 & 3.0 \\
\hline Johnson ve ark $2003^{1}$ & 11.8 & 7.2 & 6.0 & - \\
\hline Johnson ve ark $2003^{2}$ & - & 11.7 & 6.2 & 6.5 \\
\hline Johnson ve ark $2003^{3}$ & - & 9.7 & 7.4 & 5.2 \\
\hline
\end{tabular}

${ }^{1}: 1$. yıl çeşit $\mathrm{A} ;{ }^{2}: 2$. yıl çeşit $\mathrm{B} ;{ }^{3}:$ Çeşit B 
Çizelge 7. Kaliteli bir mısır silajında hedeflenen özellikler (\% KM'de)

\begin{tabular}{|c|c|c|c|}
\hline Özellikler & Ortalama & Hedef & NRC, 2001 \\
\hline KM, \% & 33 & $31-35$ & 35 \\
\hline $\mathrm{ME}, \mathrm{Mcal} / \mathrm{kg}^{1}$ & 2.35 & $2.27-2.44$ & 2.33 \\
\hline $\mathrm{NE}_{\mathrm{L}}, \mathrm{Mcal} / \mathrm{kg}^{1}$ & 1.47 & $1.41-1.52$ & 1.46 \\
\hline $\mathrm{NE}_{\mathrm{M}}, \mathrm{Mcal} / \mathrm{kg}^{1}$ & 1.60 & $1.52-1.67$ & 1.57 \\
\hline $\mathrm{NE}_{\mathrm{G}}, \mathrm{Mcal} / \mathrm{kg}^{1}$ & 1.03 & $0.95-1.11$ & 0.93 \\
\hline Ham protein, $\%$ & 7.8 & $6.6-9.0$ & 8.8 \\
\hline Ham kül, \% & 4.3 & $3.9-4.7$ & 4.3 \\
\hline Ham yağ, \% & 3.2 & $2.2-4.2$ & 3.2 \\
\hline NDF, $\%$ & 42 & $38-47$ & 45 \\
\hline $\mathrm{ADF}, \%$ & 25 & $22-28$ & 28.1 \\
\hline Lignin, \% & 2.7 & $1.8-3.5$ & 2.6 \\
\hline Lif olmayan Karbonhidrat, \% & 42 & $38-47$ & 41.9 \\
\hline Nişasta, \% & 30 & $25-35$ & - \\
\hline $\mathrm{pH}$ & 3.9 & $3.8-4.1$ & - \\
\hline Laktik asit, \% & 4.3 & $3.0-5.7$ & - \\
\hline $\mathrm{NH}_{3}-\mathrm{N}, \%$ toplam N'da & 6.2 & $2.9-9.5$ & - \\
\hline
\end{tabular}

çözünebilir karbonhidrat içeriği $30 \mathrm{~g} / \mathrm{kg} \mathrm{KM}$ olarak belirlenirken, diğer bir çalışmada (Haigh 1990), \%23 $\mathrm{KM}$ içeren bir silajda clostridial gelişimin engellenmesi için materyalin suda çözünebilir karbonhidrat içeriğinin en az $37 \mathrm{~g} / \mathrm{kg} \mathrm{KM}$ olması gerektiği bildirilmiştir. Mısır bitkisinin silolama öncesi içerdiği suda çözünebilir karbonhidrat miktarı ile birlikte düşük tampon kapasitesi ve protein içeriği de düşünüldüğünde mısır bitkisini herhangi bir gelişme döneminde etkili bir şekilde silolanmasını engelleyecek bir durum bulunmamaktadır. $\mathrm{Bu}$ nedenle misır bitkisi fermantasyon etkinliği oldukça yüksek, kolay silolanan bir bitkidir.

Silolanan materyalin KM'si düştükçe silo içerisinde daha yoğun bir silaj fermantasyonu oluşmaktadır. Yoğun bir silaj fermantasyonunun ardından silajların içerebileceği yüksek asit miktarına bağlı olarak süt sığırlarının KM tüketimleri düşebilmektedir (Huhtanen ve ark 2007). Laktik asit, toplam uçucu yağ asitleri ve amonyak-N'ın silaj KM'sindeki her \%0.1'lik artışında düzeltilmiş süt veriminin sırasıyla $\% 1.9,2.5$ ve 1.9 düştüğü bildirilmiştir (Huhtanen ve ark 2003). Bal ve ark (2000a) \%30, 32, 35 ve $42 \mathrm{KM}$ içeren misır silajlarının içerdiği laktik asit miktarını sırasıyla \%5.6, 4.7, 4.2 ve 4.0 olarak; Filya (2004) ise $\% 21,29,36$ ve $42 \mathrm{KM}$ içeren mısır silajlarının içerdiği laktik asit miktarını sırasıyla \%5.6, 4.4, 3.4 ve 1.9 olarak bildirmiştir. Görüldüğü gibi erken dişlenmede (\%21 KM) silolanmış bir misır silajı, 2/3 danedeki süt çizgisinde $(\% 36 \mathrm{KM})$ silolanmış bir mısır silajından nerede ise 2 kat daha fazla laktik asit içermektedir. Düşük KM içeriği $(<\% 30)$ ile silolamada clostridial bakterilerin etkinliklerinin artması ile silajların içerdikleri bütirik asit ve amonyak-N yüksek olabilmekte ve silo suyu çıkışı ile besin maddesi kayıpları artmaktadır. Ayrıca yoğun bir silaj fermantasyonu neticesinde oluşabilecek sıcaklık artışından dolayı besin maddelerinin sindirimi de düşmektedir (McDonald ve ark., 1991). Düşük KM ile silolama sonucunda oluşabilecek bu sorunlar silolanan materyalin düşen $\mathrm{KM}$ içeriğine paralel artmaktadır. $\mathrm{Bu}$ faktörler mısır bitkisi gibi kolay silolanabilen bir bitkide bozulmaya neden olmasa bile silajın besin ve besleme değeri ile KM kazanımlarını düşürebilecek özelliklerdir.

Bazı koşullar (iklim gibi) mısır bitkisinin istenilen hasat olgunluğuna ulaşmadan silolanmasını zorunlu kılabilmektedir. Bu tür durumlarda misır bitkisinin silolama öncesi en az \%26 KM içermesine dikkat edilmesi gerekmektedir. Çünkü \%30-25 arasında her birim KM düşüşünde, KM'deki düşüşle artmakla beraber, ortalama 1 lt/ton silo suyu çıkışı ve $\% 0.1 \mathrm{KM}$ kaybı oluşurken, \%25-20 arasındaki her birim KM düşüşünde bu değerler 11 lt/ton silo suyu çıkışı ve $\% 0.4$ KM kaybına ulaşmaktadır (Filya, 2004). Bu nedenle zorunlu durumlarda silaj yapımı sirasında öncelikle absorban etkili katkılar olmak üzere doğrudan asidifikasyon sağlayan silaj katkılarının kullanılması düşünülmelidir.

Diğer taraftan misır bitkisinin yüksek KM düzeyi $(>\% 40)$ ile silolanması durumunda fermantasyon hizı ve etkinliği düşer ve silaj fermantasyonunun kaliteli bir silaj yapımına olan etkisi de oldukça azalır (Johnson ve ark 2003; Muck 1988). Çünkü silajlık materyallerin yüksek KM içermesi laktik asit bakteri popülasyonunun gelişimini olumsuz etkilerken, maya ve küf gelişimini teşvik eder. Buna karşıın artan KM düzeyine bağlı olarak 
gelişen kısıtlı fermantasyon neticesinde gaz kayıpları düşmekte KM kazanımları artmaktadır (Johnson ve ark 2003). Filya (2004), erken dişlenmede $\% 2.9$ olan gaz kayıplarının $1 / 3,1 / 2$ ve siyah katman dönemlerinde sirasıyla $\% 1.2,0.8$ ve 0.7 olduğunu bildirmiştir. $\mathrm{Bu}$ nedenle yoğun fermantasyon riskini ortadan kaldırmak ve KM kazanımlarını artırmak için mısır bitkisinin en az $\% 32 \mathrm{KM}$ düzeyine ulaştığı dönemle hasat edilerek silolanması gerekmektedir. Bu dönemde başlatılan hasat çiftlik koşullarına bağlı olarak 3-5 gün devam etse bile (farklı silolarda, silolar aynı gün ya da en geç ertesi gün kapatılmalı) günlük ortalama $\% 0.5-0.75$ düzeyinde artacak KM neticesinde bitkinin KM'si 4. gün sonunda ancak \%34-35 düzeyine ulaşacaktır. Daha önceki bölümde değinildiği gibi silolamada \%37'en daha fazla KM hayvan performansını olumsuz etkileyebilmektedir. Ancak bu düzey KM'nin mısır silajının silolanmasında parça uzunluğu ve sıkıştırmaya dikkat edildiği sürece fermantasyon açısından bir sorun oluşturması beklenmez.

Silajl1k mısır hibritlerinin silolanmasında tavsiye edilen KM düzeylerine uyulduğu taktirde herhangi bir katkı maddesi kullanımına ihtiyaç duyulmaz. Mısır silajının düşük protein içeriğini artırmak amacıyla son biçimleri misırın hasat zamanına uyan yonca bitkisi ile istenilen ham protein düzeyinin temin edilmesi amacıyla farklı oranlarda karıştırılarak silolanabilir. Silajlık mısır hibritlerinin şeker içeriği yüksek olduğu için fermantasyon sonucunda arta kalan şeker miktarı da fazla olmaktadır. Bu nedenle silajın aerobik stabilitesini artırmak amaciyla tercihen $L$. bucheri'yi tek ya da karışım halinde içeren bakteri inokulantları biçme ya da silolama esnasında uygulanabilir (Keles ve Yazgan, 2011).

\section{Mısır silajlarının hedeflenen özellikleri}

Kaliteli bir mısır silajının içermesi gereken besin değerinin bir ölçüsü olarak, bu derleme çalışmasında kullanılan 18 çalışmadan elde edilen 42 adet veriye ait ortalama değerler ve bunların standart sapmadan uzaklıkları, hedef değerler olarak Çizelge 7'de verilmiştir. Kontrollü şartlarda yürütülen bu çalışmaların tamamı erken dişlenme- $2 / 3$ süt çizgisinde silolanmış ve $\% 30-35$ arasında $\mathrm{KM}$ içeren silajlara ait değerlerdir. Hedef süt çizgisinde (1/3-2/3) silolanmış ancak KM düzeyi $\% 30$ 'dan düşük ya da $\% 35$ 'den yüksek silajlar ortalamaya dahil edilmemiştir. Çizelge incelendiğinde elde edilen ortalama değerlerin NRC (2001) tarafindan bildirilen \%32-38 KM'li misır silajlarının değerlerine oldukça yakın olduğu görülmektedir. Çizelge 7'deki değerler iyi bir mısır silajında bulunması beklenen özelliklerdir. Bunun yanında enerji değerleri, ham protein, nişasta ve ham yağın üst değerlere yakın ya da yüksek, hücre duvarı karbonhidratları, $\mathrm{pH}$ ve amonyak-N'inin ise alt değerlerde yakın ve daha düşük olması elde edilecek silajların besleme değerinin çok daha iyi olduğuna işaret edecektir.

\section{Sonuç}

Danedeki benzer süt çizgisinde hasat edilmiş farklı silajlık misır hibritlerinin silolama öncesi içermiş oldukları KM düzeyi çeşit ve iklim koşullarına bağlı olarak silajın besleme değerini etkileyebilecek ölçüde farklılıklar gösterebilmektedirler. Bu nedenle kullanılan silajlık mısır hibritlerinde danedeki süt çizgisi ile bitkinin KM düzeyi arasındaki ilişkinin bilinmesi gerekmektedir. Hedeflenen KM düzeyi ile silolama amaciyla en iyi yöntem silolama öncesi belirli periyotlarla tarladan alınacak örneklerde bitki KM'sini belirlemektir.

Silajlık misır hibritlerinde KM verimi ve besin değerinin senkronizasyonu danedeki süt çizgisinin 1/22/3 olduğunda dönemde gerçekleşmektedir.

Yüzde 36'dan daha yüksek KM içeren silajlarla beslenen ineklerin verimleri düşebilmektedir.

Süt ineklerinin performansları üzerine silajlık misır hibrit çeşitlerinin içerdikleri NDF miktarlarından daha ziyade NDF sindirilebilirliğinin etkisi çok daha belirgin olmaktadır. Farklı silajlık misır hibritleri arasında besleme değeri bakımından farklılıklar bulunsa da, bu farklılıkların çok belirginlik ve süreklilik arz etmemektedir. Mısır silajının besleme değerinin performans üzerine etkisi yüksek verimli süt ineklerinde (>40 kg/gün) daha belirgin olmakta ve rasyonda kullanılan diğer kaba yemin özelliklerinden etkilenmektedir. $\mathrm{Bu}$ nedenle silajlık mısır çeşidi seçiminde KM verimi, bitki zararlılarına dayanıklılık, adaptasyon gibi agronomik özelliklerin de göz önünde bulundurulması gerekmektedir.

Koçana silolama öncesi uygulanan mekaniksel işlemenin \%32-40 arasında KM içeren silajlarda nişasta sindirilebilirliğini artırdığı belirlenmiştir. Ancak nişasta sindirilebilirliğindeki bu artışın hayvan performansı üzerine olumlu olması beklenen etkileri belirginlik ve süreklilik arz etmemektedir. Bununla beraber, dışkıda gözlenen bütün haldeki misır daneleri mısır bitkisin silolama öncesi artan KM düzeyi ve parçalama uzunluğuna paralel olarak mekaniksel işlemenin gerekliliğinin artacağını düşündürmektedir. 
Silajlık mısır hibritlerinin silolama öncesi farklı parçalama uzunluklarının süt ineklerinin performansı üzerine herhangi bir etkileri bulunmamaktadır. Bununla beraber silajlık misır hibritlerinin silolama öncesi 0.9-2 cm boyutlarında parçalanması, silo içerisinde birim alana daha fazla silajın depolanması ve koçanın daha etkin parçalanmasını temin etmesi bakımından daha uzun parça uzunluklarına tercih edilmelidir. Ayrıca parçalama uzunluğu ve mekaniksel işlemin birlikte değerlendirilmesi ve bu işlemlere karar verilirken rasyonda kullanılacak diğer kaba yem kaynaklarının etkili NDF içeriklerinin göz önünde bulundurulması da gerekmektedir.

Sonuç olarak silajlık misır hibritlerinin KM verimi, besin ve besleme değerleri değerlendirildiğinde besin değeri ve KM madde veriminin optimum olduğu $1 / 3$ 2/3 süt çizgisinde hasat edilmesi gerekmektedir. Ancak çeşitler arasındaki KM farklılıklarından dolayı, hibritlerin hasadında danedeki süt çizgisi ve bitkinin KM'sinin beraber değerlendirilmesi gerekmektedir. Bu nedenle silajlık mısır hibritleri \%32-36 KM içerdikleri dönemde danedeki süt çizgisi $1 / 3-2 / 3$ ise hasat edilmeleri gerekmektedir. Böylece \%30-35 arasında KM içeren mısır silajları üretilmiş olacaktır.

\section{Kaynaklar}

Andrae, J.G., Hunt, C.W., Pritchard, G.T., Kennington, L.R., Harrison, J.H., Kezar, W., Mahanna, W. 2001. Effect of hybrid, maturity, and mechanical processing of corn silage on intake and digestibility by beef cattle. J. Anim. Sci. 79: 2268-2275.

Bagg, J. 2007. Harvesting corn silage at the right moisture.

Factsheet. http://www.omafra.gov.on.ca/english/crops/facts/07047.htm. (Erişim: 30.05.2013).

Bal, M.A., Coors, J.G., Shaver, R.D. 1997. Impact of the maturity of corn for us as silage in the diets of dairy cows on intake, digestion, and milk production. J. Dairy Sci. 80: 2497-2503.

Bal, M.A., Shaver, R.D., Jirovec, A.G., Shinners, K.J., Coors, J.G. 2000a. Crop processing and chop length of corn silage: Effects on intake, digestion, and milk production by dairy cows. J. Dairy Sci. 83: 12641273.

Bal, M.A., Shaver, R.D., Al-Jobeile, H., Coors, J.G., Lauer, J.G. 2000b. Corn silage hybrid effects on intake, digestion, and milk production by dairy cows. J. Dairy Sci. 83: 2849-2858.

Ballard, C.S., Thomas, E.D., Tsang, D.S., Mandebvu, P., Sniffen, C.J., Endres, M.I., Carter, M.P. 2001. Effect of corn silage hybrid on dry matter yield, nutrient composition, in vitro digestion, intake by dairy heifers, and milk production by dairy cows. J.
Dairy Sci. 84: 442-452.

Browne, E.M., Juniper, D.T., Bryant, M.J., Beever, D.E. 2005. Apparent digestibility and nitrogen utilization of diets based on maize silage harvested at three stages of maturity and fed to steers. Grass Forage Sci. 60: 274-282.

Cammell, S.B., Sutton, J.D., Beever, D.E., Humphries, D.J., Phipps R.H. 2000. The effect of crop maturity on the nutritional value of maize silage for lactating dairy cows: 1. Energy and nitrogen utilization. Anim. Sci. 71: 381-390.

Castro, J.J., Bernard, J.K., Mullis, N.A., Eggleston, R.B. 2010. Brown midrib corn silage and Tifton 85 bermudagrass in rations for early-lactation cows. J. Dairy Sci. 93: 2143-2152.

Cox, B. 2008. What's cropping up? A Newsletter for New York filed crops \& soils. http://css.cals.cornell.edu/extension/croppingup/archive (Erişim: 30.05.2013).

Dhiman, T.R., Bal, M.A., Wu, Z., Moreira, V.R., Shaver, R.D., Satter, L.D., Shinners, K.J., Walgenbach, R.P. 2002. Influence of mechanical processing on utilization of corn silage by lactating dairy cows. J. Dairy Sci. 83:2521-4814.

Fernandez, I., Martin, C., Champion, M., MichaletDoreau, B. 2004. Effect of corn hybrid and chop length of whole-plant corn silage on digestion and intake by dairy cows. J. Dairy Sci. 87: 1298-1309.

Ferraretto, L.F., Shaver, R.D. 2012. Meta-analysis: Effect of corn silage harvest practices on intake, digestion, and milk production by dairy cows. The professional Animal Scientist 28: 141-149.

Filya, İ. 2004. Nutritive value and aerobic stability of whole crop maize silage harvested at four stages of maturity. Anim. Feed Sci. Tech. 116: 141-150.

Filya, İ. 2006. Silaj yapımı, teknolojisi ve kullanımı. Sütaş. Hayvancılık Serisi: 2. Bursa.

Gencoglu, H., Shaver, R., Lauer, J. 2008. Brown midrib corn silage for lactating dairy cows: A contemporary review.

http://www.uwex.edu/ces/dairynutrition/pubs.cfm. (Erişim: 30.05.2013)

Haigh, P.M., Parker, J.W.G. 1985. Effect of silage additives and wilting on silage fermantation, digestibility and intake, and on liveweight change of young cattle. Grass Forage Sci. 40: 429-436.

Haigh, P.M. 1990. Effect of herbage water-soluble carbohydrate content and weather conditions at ensilage on the fermantation of grass silages made on commercial farms. Grass Forage Sci. 45: 263271.

Holt, M.S., Eun, J-S., Thacker, C.R., Young, A.J., Dai, X., Nestor, K.E. 2013. Effects of feeding brown 
midrib corn silage with a high dietary concentration of alfalfa hay on lactational performance of Holstein dairy cows for the first 180 days of lactation. J. Dairy Sci. 96: 515-523.

Holt, M.S., Williams, C.M., Dschaak, C.M., Eun, J-S., Young, A.J. 2010. Effects of corn silage hybrids and dietary nonforage fiber sources on feed intake, digestibility, ruminal fermentation, and productive performance of lactating Holstein dairy cows. J. Dairy Sci. 93: 5397-5407.

Huhtanen, P., Nousiainen, J.I., Khalili, H., Jaakkola, S., Heikkila, T. 2003. Relationships between silage fermantation characteristics and milk production parameters: analyses of literature data. Lives. Prod. Sci. 81: 57-73.

Huhtanen, P., Rinne, M., Nousiainen, J. 2007. Evaluation of the factors affecting silage intake of dairy cows: a revision of the relative silage drymatter intake index. Lives. Prod. Sci. 81: 57-73.

Johnson, L.M., Harrison, J.H., Hunt, C., Shinners, K., Doggett, C.G., Sapienza, D. 1999. Nutritive value of corn silage as affected by maturity and mechanical processing: A contemporary review. J. Dairy Sci. 82: 2813-2825.

Johnson, L.M., Harrison, J.H., Davidson, D., Swift, M., Mahanna, W.C., Shinners, K. 2002a. Corn silage management III: Effects of hybrid, maturity, and mechanical processing on nitrogen metabolism and ruminal fermentation. J. Dairy Sci. 85: 2928-2947.

Johnson, L.M., Harrison, J.H., Davidson, D., Robutti, J.L., Swift, M., Mahanna, W.C., Shinners, K. 2002b. Corn silage management I: Effects of hybrid, maturity, and mechanical processing on chemical and physical characteristics. J. Dairy Sci. 85: 833853.

Johnson, L.M., Harrison, J.H., Davidson, D., Mahanna, W.C., Shinners, K. 2003. Corn silage management: Effects of hybrid, maturity, inoculation and mechanical processing on fermentation characteristics. J. Dairy Sci.86: 287-308.

Keles, G., Yazgan, O. 2011. Fermentation characteristics of maize silages ensiled with lactic acid bacteria and the effect of inoculated baled maize silages on lamb performance. Kafkas Univ. Vet. Fak. Derg. 17(2): 229-234.
Khan, N.A., Tewoldebrhan, T.A., Zom, R.L.G., Cone, J.W., Hendriks, W.H. 2012. Effect of corn silage harvest maturity and concentrate type on milk fatty acid composition of dairy cows. J. Dairy Sci. 95: 1472-1483.

Kung, L., Moulder, B.M., Mulrooney, C.M., Teller, R.S., Schmidt, R.J. 2008. The effect of silage cutting height on the nutritive value of a normal corn silage hybrid compared with brown midrib corn silage fed to lactating cows. J. Dairy Sci. 91: 1451-1457.

McDonald. P., Henderson, N., Heron, S.J.R. 1991. The Biochemistry of Silage. 2th ed. 340 page, Chalcombe Publications, Marlow, UK.

Mertens, D.R. 1997. Creating a system for meeting the fiber requirements of dairy cow. J. Dairy Sci. 80: 1463-1481.

Muck, R.E. 1988. Factors influencing silage quality and their implications for management. J. Dairy Sci. 71: 2992-3002.

NRC, 2001. National Research Council. Nutrients requirements of dairy cattle. The national academic press. Washington DC

Phipps, R.H., Sutton, J.D., Beever, D.E., Jones A.K. 2000. The effect of crop maturity on the nutritional value of maize silage for lactating dairy cows: 3 . Food intake and milk production. Anim. Sci. 71: 401-409.

Schwab, E.C., Shaver, R.D., Shinners, K.J., Lauer, J.G., Coors, J.G. 2002. Processing and chop length effects in brown-midrib corn silage on intake, digestion, and milk production by dairy cows. J. Dairy Sci. 85: 613-623.

Shinners, K.J., Jirovec, A.G., Shaver, R.D., Bal, M.A. 2000. Processing whole-plant corn silage with crop processing rolls on a full-type forage harvester. Appl. Eng. Agric..16: 323-331.

Weiss, W.P., Wyatt, D.J. 2000. Effect of oil content and kernel processing of corn silage on digestibility and milk production by dairy cows. J. Dairy Sci. 83: 351-358.

Wiersma, D.W., Carter, P.R., Albrecht, K.A., Coors, J.G. 1993. Kernel milk line stage and corn forage yield, quality and dry matter content. J. Prod. Agric. 6: 94-99. 